\title{
Inhibition of biofilm bacteria and adherent fungi from marine plankton cultures using an antimicrobial combination
}

\author{
Vanessa Ochi Agostini $\mathbb{D} \cdot$ Alexandre José Macedo $\cdot$ Erik Muxagata
}

Received: 6 December 2017/Accepted: 19 May 2018/Published online: 31 May 2018

(C) The Author(s) 2018

\begin{abstract}
The presence of organic matter in plankton cultures will lead to 10- to 1000-fold increases in bacterial density in less than $24 \mathrm{~h}$. The presence of bacteria and fungi can damage cultivated phytoplankton and zooplankton. These microorganisms can also inhibit experiments investigating the role of these microorganisms in the community and in biological and ecological laboratory studies. The aim of this study was thus to evaluate the effect of penicillin + streptomycin + neomycin (antibiotics) in combination with nystatin (antifungal) to select an antimicrobial combination for the inhibition of biofilm bacteria and adherent fungi that is effective and also non-toxic to marine phytoplankton and zooplankton. Acartia tonsa was exposed to different antimicrobial treatments and application routes (culture medium, culture food, both) to evaluate the survival and egg and fecal pellet production endpoints. The same treatments were also applied to measure Amphibalanus improvisus survival and settlement and Conticribra weissflogii growth endpoints. We selected the most sensitive experimental organism and exposed it to some novel antimicrobial combinations. To evaluate the inhibition potential, biofilm bacteria and adherent fungi were exposed to the treatments that were safe for the bioindicator species. A tonsa was considered the most sensitive of all tested organisms. The treatment composed of $0.025 \mathrm{~g} \mathrm{~L}^{-1}$ penicillin $\mathrm{G}$ potassium $+0.08 \mathrm{~g} \mathrm{~L}^{-1}$ streptomycin sulfate $+0.04 \mathrm{~g} \mathrm{~L}^{-1}$ neomycin sulfate showed the best results for $A$. tonsa and $C$. weissflogii cultures. No differences were observed for A. improvisus between the treatments. A. tonsa survival rates showed no differences from the
\end{abstract}

V. O. Agostini $(\bowtie) \cdot$ E. Muxagata

Laboratório de Zooplâncton - Instituto de Oceanografia da Universidade Federal do Rio Grande (FURG), Caixa Postal, 474, CEP: 96203-900 Rio Grande, RS, Brazil

e-mail: nessaochi@gmail.com

V. O. Agostini

Programa de Pós-graduação em Oceanografia Biológica (PPGOB), Bolsista do Conselho Nacional de Desenvolvimento Científico e Tecnológico (CNPq), Rio Grande, Brazil

Present Address:

V. O. Agostini

Laboratório de Microcontaminantes Orgânicos e Ecotoxicologia Aquática, CAPES Postdoctoral fellow at Programa de PósGraduação em Oceanografia Física, Química e Geológica, Instituto de Oceanografia, Universidade Federal do Rio Grande, Rio Grande, Brazil

A. J. Macedo

Laboratório de Biofilmes e Diversidade Microbiana - Faculdade de Farmácia e Centro de Biotecnologia da Universidade Federal do Rio Grande do Sul (UFRGS), Av. Ipiranga, 2752, Bairro Azenha, 90610-000 Porto Alegre, RS, Brazil 
control at nystatin concentrations up to $0.005 \mathrm{~g} \mathrm{~L}^{-1}$ in combination with the antibiotics. The biofilm bacterial density decreased up to $94 \%$ under this treatment, and fungal growth was prevented. Species of other planktonic groups should also be tested to improve our understanding of the effectiveness of the treatments proposed.

Keywords Antibiotics · Antifungal · Bioassay $\cdot$ Holoplankton · Meroplankton $\cdot$ Phytoplankton

\section{Introduction}

Different groups of planktonic organisms, such as phytoplankton and zooplankton, have been cultivated in semi-intensive and intensive systems for ecological and biological studies as live food in aquaculture, as well as for toxicological tests (Gilles et al. 2013; Edwards et al. 2016; Lopes et al. 2018). Unicellular marine algae are commonly grown as food for several commercially valuable marine organisms (e.g., fishes, crustaceans, mollusks) (Riquelme and Avendaño-Herrera 2003; Gilles et al. 2013). Copepods and barnacle larvae are used as live food in aquaculture for fishes (Støttrup 2000; López et al. 2010). Microalgae, copepods, and barnacles are also increasingly used as bioindicator species in ecotoxicology (Raisuddin et al. 2007; Buttino et al. 2012; Cid et al. 2012; Piazza et al. 2012; Lopes et al. 2018) and as models to predict the impact of chemicals on communities. These organisms are also cultivated to investigate species and population characteristics (growth, development, interactions, production, settlement, and life cycles) (Thiyagarajan et al. 2003a, b; Lee et al. 2013; Freckelton et al. 2017).

The presence of small amounts of organic matter in cultures can lead to a 10- to 1000-fold increase in bacteria in less than $24 \mathrm{~h}$ (D'Agostino 1975). Such rapid microbial growth is often accompanied by marked decreases in $\mathrm{pH}$, dissolved oxygen, and concentrations of dissolved nutrients, as well as the release of potentially toxic bacterial metabolites (Fitt et al. 1992; Carvalho and Fernandes 2010). Bacteria associated with diatoms are usually very tenaciously attached, and some may penetrate the gelatinous sheaths and harm phytoplankton (Subhash et al. 2004; Hamdan and Jonas 2007). Bacteria have the potential to negatively affect the growth and reproduction of crustaceans (Wang 2011; Edlund et al. 2012) and are associated with failures in the development of zooplankton cultures (Agostini et al. 2016).

Pathogenic microbes (i.e., virus, bacteria, fungi) generally invade cultures by three principal routes: culture medium, broodstock, and food. Numerous studies have investigated chemical (antibiotics, hypochlorite, iodine, hormones, phenol and detergents) and physical (membrane filtration, autoclave, ultraviolet light, and sonication) treatments aiming to inhibit these microorganisms without negatively affecting the cultivation of eukaryotic organisms (i.e., algae, mollusks, crustaceans) (Spencer 1952; McCracken 1989; Skjermo and Vadstein 1999; Hamdan and Jonas 2007; Liu et al. 2012; Scholz 2014; Agostini et al. 2016). Most studies used different chemicals (mainly the antibiotics penicillin, streptomycin and neomycin) to inhibit bacterial activity without preliminary tests to ensure that the chemical would not affect experimental organisms (Spencer 1952; Droop 1967; McCracken 1989; Skjermo and Vadstein 1999). Most of these studies also used one antibiotic alone and assumed inhibition of the target microorganisms without previously testing the efficiency of these chemicals.

The importance of antibiotics in controlling bacterial growth in marine cultures has been recognized since the 1940s, when they were used in protozoan cultures (Ithaca and Mahmoud 1944). The advantage of antimicrobials over all other methods is their efficiency in microbial inhibition combined with the availability of several different types of antimicrobials. It remains uncertain, however, whether the experimental animals (non-target organisms) would be affected by exposure to these antibiotics. Antibiotics combinations have broad-spectrum bacterial inhibition, but some authors have emphasized that the niche provided by these prokaryotes may be occupied by filamentous fungi and/or yeasts. Application of antifungals would thus inhibit these fungi (Provasoli et al. 1951; Tang et al. 2006; Agostini 2014; Agostini et al. 2016).

The application of antibiotics and antifungals (i.e., antimicrobials) in planktonic cultures can prevent disease and competition (Agostini et al. 2016). This allows ecological studies of the role of bacteria and fungi in aquatic communities (Trottet et al. 2011) and biological (genetic, taxonomy, development, and growth) studies without bacterial or fungal interference (Howes et al. 2014). The goal of this study was thus to evaluate the effect of a combination of penicillin, streptomycin and neomycin with an antifungal agent to select the 
most effective concentration for preventing bacterial and fungal growth without negatively affecting phytoplankton or zooplankton organisms. The novelty of the present study is the evaluation of the effect of antimicrobial (prokaryote and eukaryote inhibitors) combinations on target and experimental organisms.

\section{Materials and methods}

This study consisted of experiments to evaluate the effects of different antibiotics (penicillin, streptomycin and neomycin) at different concentrations (Agostini et al. 2016; DeLorenzo et al. 2001) administered in combination with nystatin (Finley 2012) (Table 1) to plankton cultures. The experimental organisms evaluated were Acartia tonsa Dana 1849 (Copepoda: Calanoida), Amphibalanus improvisus (Darwin 1854) (Crustacea: Cirripedia), and Conticribra weissflogii (Grunow) Stachura-Suchoples \& Williams (Ochrophyta: Bacillariophyceae). These organisms represent zooplankton (holoplankton and meroplankton) and phytoplankton, respectively.

The animals were obtained from zooplankton samples collected by means of horizontal tows performed at the surf zone of Cassino Beach, Rio Grande, RS, Brazil. All samples were collected with a conventional $200-\mu \mathrm{m}$ plankton net with a 30-cm mouth diameter. The microalgae $C$. weissflogii were obtained from cultures kept at the Marine Phytoplankton and Microorganisms Laboratory of the Federal University of Rio Grande in F/2 medium (Guillard 1975) at salinity 30, temperature $25 \pm 1{ }^{\circ} \mathrm{C}$ and a 12hL:12hD (Light:Dark) photoperiod under 70 mol photons s$~^{-1} \mathrm{~m}^{-2}$ artificial illumination inside BOD incubators (Marconi 403).

Copepods and barnacles were identified in the laboratory (Sabatini 1990; Jones and Crisp 1954, respectively). Healthy specimens of $A$. tonsa and A. improvisus were manually picked using Pasteur pipettes under a stereoscopic microscope (Olympus SZ40). All specimens were classified according to the development stage (i.e., copepodites VI males and females of A. tonsa and nauplius VI of A. improvisus to obtain cyprids of the same age after metamorphosis). Before the experiments were performed, the organisms were submitted to a 30-h acclimation under similar field conditions (e.g., salinity 30 , temperature $25{ }^{\circ} \mathrm{C}$ and a $14 \mathrm{hL}: 10 \mathrm{hD}$ photoperiod) to remove any organism that had been injured or debilitated by stress inherent in collection and sorting. Adults of Acartia tonsa and nauplius VI of A. improvisus were acclimated separately.

After acclimation, eight replicates containing two copepods, one male and one female, were placed in 50-mL experimental units (EUs) (density of 1 org $25 \mathrm{~mL}^{-1}$ ). Each EU was fitted with a $140-\mu \mathrm{m}$ mesh to separate the copepod eggs and fecal pellets produced (Runge and Roff 2000). Copepods were exposed to different antimicrobial treatments (Table 1) following different application routes: antimicrobial applications only in the copepod culture medium (M), only in the culture medium of their food (F), and in the culture media of both the copepods and their food (M/F). The experiment was static; in this way, the treatments were applied once per culture (time 0 ). Recently molted cyprid larvae were deposited in each EU individually (1 org $20 \mathrm{~mL}^{-1}$ ) under the same acclimation conditions, with six replicates per treatment for barnacles. Cyprids were then exposed to different antimicrobial treatments, as indicated in Table 1, and the experiment was static.

The copepod and barnacle cultures were observed every $24 \mathrm{~h}$ for $96 \mathrm{~h}$. Eggs and fecal pellets produced by copepods were counted only at the end of the experiment $(96 \mathrm{~h})$ to evaluate the effects of the treatments on reproduction and feeding, respectively. Copepods were fed daily with the diatom $C$. weissflogii at a

Table 1 Summary of the treatments tested on experimental (copepod, barnacle, microalgae) organisms

\begin{tabular}{|c|c|}
\hline Abbreviature & Composition \\
\hline Control & Untreated \\
\hline$T_{\mathrm{A}}$ & $\begin{array}{l}0.025 \mathrm{~g} \mathrm{~L}^{-1} \text { penicillin } \mathrm{G} \text { potassium }+0.08 \mathrm{~g} \mathrm{~L}^{-1} \text { streptomycin sulfate }+0.04 \mathrm{~g} \mathrm{~L}^{-1} \text { neomycin sulfate (Agostini } \\
\text { et al. 2016) }\end{array}$ \\
\hline$T_{\mathrm{A}+\text { nystatin }}$ & $\begin{array}{l}0.025 \mathrm{~g} \mathrm{~L}^{-1} \text { penicillin } \mathrm{G} \text { potassium }+0.08 \mathrm{~g} \mathrm{~L}^{-1} \text { streptomycin sulfate }+0.04 \mathrm{~g} \mathrm{~L}^{-1} \text { neomycin sulfate }+0.05 \mathrm{~g} \\
\mathrm{~L}^{-1} \text { of nystatin }\end{array}$ \\
\hline$T_{\mathrm{D}}$ & $\begin{array}{l}0.025 \mathrm{~g} \mathrm{~L}^{-1} \text { penicillin } \mathrm{G} \text { potassium }+0.04 \mathrm{~g} \mathrm{~L}^{-1} \text { streptomycin sulfate }+0.08 \mathrm{~g} \mathrm{~L}^{-1} \text { neomycin sulfate } \\
\text { (DeLorenzo et al. 2001) }\end{array}$ \\
\hline$T_{\mathrm{D}+\text { nystatin }}$ & $\begin{array}{l}0.025 \mathrm{~g} \mathrm{~L}^{-1} \text { penicillin } \mathrm{G} \text { potassium }+0.04 \mathrm{~g} \mathrm{~L}^{-1} \text { streptomycin sulfate }+0.08 \mathrm{~g} \mathrm{~L}^{-1} \text { neomycin sulfate }+0.05 \mathrm{~g} \\
\mathrm{~L}^{-1} \text { nystatin }\end{array}$ \\
\hline
\end{tabular}


concentration of 20,000 cells $\mathrm{mL}^{-1}$ (Teixeira et al. 1896). Because cyprids do not feed at this stage, no food was added to their EU.

In the experiments with the microalgae $C$. weissflogii, the initial concentration was 31 cells $\mathrm{mL}^{-1}$ in $200 \mathrm{~mL}$ of medium, with six replicates per treatment. The same growing conditions were maintained, with the exception of the photoperiod, which was changed to $14 \mathrm{hL}: 10 \mathrm{hD}$ to follow the same conditions of the experiments with the zooplankton. Due to the absence of aerators, the EUs were shaken every $6 \mathrm{~h}$ to prevent sedimentation of the cells. The experiment was static. To follow the growth of $C$. weissfogii, $2 \mathrm{~mL}$ of each culture was sampled at 24, 96, and $168 \mathrm{~h}$ at the same time and after homogenization of the EU. This subsample was deposited in Eppendorf tubes and preserved with lugol (1\%). Cell counts were performed in Neubauer chambers under a microscope $(40 \times-$ Olympus BH-2) to quantify growth (density per exposure time) and yield (final cell density - initial cell density).

After the first set of experiments, the antifungal nystatin was added at different concentrations (based on Lopes 2014) to the antibiotic combinations that produced the highest survival and production rates of $A$. tonsa compared to the control (Table 1). This new set of treatments (Table 2) was performed in two steps. In the first step, the survival of the calanoid copepod A. tonsa under the treatments was assessed (Table 2). In the second step, the efficacy on the inhibition of biofilm bacteria and adhered fungi in marine cultures and the half-life of the best antimicrobial combinations obtained in the first step were investigated.

Individuals of $A$. tonsa were collected from zooplankton tows and acclimated under the same conditions as described above. After acclimation, adult organisms were separated without sex distinction (ISO 14669 1999) and placed in pairs in each EU with $40 \mathrm{~mL}$ of culture medium (1 org $20 \mathrm{~mL}^{-1}$ ) (Lopes et al. 2018), representing seven treatments with ten replicates each (Table 2). The cultures were kept under the same

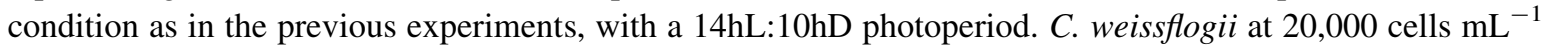
(Teixeira et al. 1896) was added daily to each EU as food. The experiment was semi-static, with the culture medium renewed daily. To evaluate the impact of treatments on copepod survival, each EU was observed every $24 \mathrm{~h}$ for $96 \mathrm{~h}$.

To evaluate the antimicrobial efficacy and half-life, eight substrates of wood $(20 \times 10 \mathrm{~mm})$ that had been previously cleaned with 70\% ethyl alcohol (Caixeta et al. 2012; Agostini et al. 2017) were placed in each EU $(120 \mathrm{~mL})$, with three replicates per treatment. To prevent biofilm colonization on only one side of the wooden substrates, the EUs were shaken five times a day. All EUs were kept under the same conditions as in the previous experiments inside a BOD incubator (Marconi 403). To assess the initial effects of the antibiotics as well as the half-life in artificial seawater, the experiment was static, and antimicrobials were applied only once (time 0).

To estimate the biofilm bacterial density, three aliquots from three substrates were taken after 3, 6, 9, 12 , $15,18,21,24$ and $168 \mathrm{~h}$ of exposure (based on Lopes 2014) and placed in sterile saline solution (20 mL). The microorganisms had to be detached from the wooden substrates using three pulses of $20 \mathrm{kHz}$ for $15 \mathrm{~s}$ on each side of the substrate (Oliveira et al. 2006) using a Cole-Parmer ${ }^{\circledR}$ ultrasound (series 4710). The detached biofilm solution was fixed with $4 \%$ sterile formaldehyde, placed inside Eppendorf tubes, and stored in the dark at $8{ }^{\circ} \mathrm{C}$ until analysis. Biofilm bacterial density $\left(\right.$ org $\mathrm{cm}^{-2}$ ) was estimated in a flow cytometer (BD FACSVerse $^{\mathrm{TM}}$ ) at the Faculty of Pharmacy of the Federal University of Rio Grande do Sul (UFRGS) (Agostini et al. 2016, 2017).

Table 2 Summary of the treatments tested on target (bacteria and fungi) and experimental (copepod, barnacle, microalgae) organisms

\begin{tabular}{ll}
\hline Abbreviature & Composition \\
\hline Control & Untreated \\
$T_{\mathrm{A}}$ & $\begin{array}{r}0.025 \mathrm{~g} \mathrm{~L}^{-1} \text { penicillin G potassium }+0.08 \mathrm{~g} \mathrm{~L}^{-1} \text { streptomycin sulfate }+0.04 \mathrm{~g} \mathrm{~L}^{-1} \text { neomycin sulfate (Agostini } \\
\quad \text { et al. 2016) }\end{array}$ \\
$\begin{array}{l}T_{\mathrm{A}}+\mathrm{n}_{1} \\
T_{\mathrm{A}}+\mathrm{n}_{2}\end{array}$ & $\begin{array}{l}T_{\mathrm{A}}+0.0025 \mathrm{~g} \mathrm{~L}^{-1} \text { nystatin } \\
T_{\mathrm{A}}+\mathrm{n}_{3}\end{array}$ \\
$T_{\mathrm{A}}+\mathrm{n}_{4}$ & $T_{\mathrm{A}}+0.005 \mathrm{~g} \mathrm{~L}^{-1}$ nystatin \\
$T_{\mathrm{A}}+\mathrm{n}_{5}$ & $T_{\mathrm{A}}+0.015 \mathrm{~g} \mathrm{~L}^{-1}$ nystatin \\
\hline
\end{tabular}


To evaluate the microbial community, biological material (of water and substrate) obtained from the EUs was filtered on polycarbonate filters (darkened with irgalan black), stained with acridine orange (1\%) and viewed under an epifluorescence microscope (Zeiss Axioplan) at $1000 \times$ magnification. The presence or absence of fungi was also recorded, and bacterial morphotypes were classified (Zaritski 1975). The size ( $\mu \mathrm{m}$ ) and cell complexity were evaluated using the mode Forward Light Scatter (FSC-A) and Light Side Scatter (SSC-A) parameters using 6- $\mu \mathrm{m}$ latex beads (Molecular Probes ${ }^{\circledR}$ ) as the standard (Herzenberg et al. 2006; Bouvier et al. 2011; Picot et al. 2012). The cell size $(\mu \mathrm{m})$ estimated by flow cytometry was compared with measurements performed over epifluorescence photos (100 bacteria manually measured). The bacterial cell biovolume $\left(\mu \mathrm{m}^{3}\right)$ estimation (Sun and Liu 2003) and conversion to bacterial cell biomass (pg C cell ${ }^{-1}$ ) were made using the allometric conversion factor $\left(0.09 *\right.$ biovolume $\left.^{0.09}\right)$ (Norland 1993).

General linear model (GLM) analysis was performed for A. tonsa survival and production, A. improvisus survival and settlement, and $C$. weissflogii and bacterial growth at each exposure time using a statistical computing package ( $\mathrm{R}$ Development Core Team 2016). The model used was adapted to the data with a binomial distribution (survival and settlement) with a "logit" link function and a Poisson distribution (growth and production) with a "log" link function. Post hoc Tukey's test was performed after the analyses. After analysis, antimicrobials were stored in sealed containers and collected by the Engineering and Environmental Services, SANIPLANC.

\section{Results}

Significant survival rates of Acartia tonsa among treatments were observed. Significant differences occurred among the antimicrobial treatments applied in $\mathrm{M}$ after $48 \mathrm{~h}$ of exposure. At $48 \mathrm{~h}, 100,100,38,88$ and $25 \%$ survival rates were observed in the control, $T_{\mathrm{A}}, T_{\mathrm{A}+\text { nystatin, }} T_{\mathrm{D}}$ and $T_{\mathrm{D}+\text { nystatin }}$, respectively. $T_{\mathrm{D}+\text { nystatin }}$ was significantly different from the control $(p<0.028)$ and $T_{\mathrm{A}}(p<0.028)$. At $72 \mathrm{~h}$ of exposure, $T_{\mathrm{A}+\text { nystatin }}$ and $T_{\mathrm{D}+\text { nystatin }}$ showed lower survival rates (13 and $0 \%$, respectively), being different from all treatments ( $p<0.029$ ). At $96 \mathrm{~h}$ of exposure, no significant difference was observed between the control and the $T_{\mathrm{A}}$ and $T_{\mathrm{D}}$ treatments $(p>0.985)$; copepod survival rates were 88,88 and $75 \%$, respectively (Fig. 1a). When antimicrobials were applied only in F, no significant differences were observed $(p>0.441)$ (Fig. $1 \mathrm{~b})$. At $96 \mathrm{~h}$ of exposure, the average survival was $88,75,50,63$ and $63 \%$ for the control, $T_{\mathrm{A}}, T_{\mathrm{A}+\text { nystatin }}, T_{\mathrm{D}}$ and $T_{\mathrm{D}+\text { nystatin }}$, respectively. When antimicrobials were applied in $\mathrm{M} / \mathrm{F}$, differences were observed from $48 \mathrm{~h}$ of exposure, where $100,88,0,75$ and $38 \%$ survival were recorded in the control, $T_{\mathrm{A}}, T_{\mathrm{A}+\text { nystatin }}, T_{\mathrm{D}}$ and $T_{\mathrm{D}+\text { nystatin }}$, respectively. $T_{\mathrm{A}+\text { nystatin }}(p<0.002)$ was significantly different from the control, as well as from $T_{\mathrm{A}}$ $(p<0.007)$ and $T_{\mathrm{D}}(p=0.027)$. At $72 \mathrm{~h}, T_{\mathrm{A}+\text { nystatin }}$ and $T_{\mathrm{D}+\text { nystatin }}$ showed no survivors, differing from all treatments $(p<0.028)$. At the end of the experiment $(96 \mathrm{~h})$, no significant difference was observed between the control $(88 \%)$ and the $T_{\mathrm{A}}\left(88 \%\right.$ survival) and $T_{\mathrm{D}}(75 \%$ survival) treatments (Fig. 1c).

Significant differences in the egg production of $A$. tonsa (female ${ }^{-1} \mathrm{day}^{-1}$ at $96 \mathrm{~h}$ ) between treatments $(p<0.001)$ were observed (Fig. 1d). $T_{\mathrm{A}}$ showed higher average egg production than the control $(20 \pm 3)$, with significant differences when antimicrobials were applied in $\mathrm{M}(p<0.001), \mathrm{F}(p<0.048)$, and $\mathrm{M} / \mathrm{F}$ $(p<0.001)$ at $49 \pm 6,27 \pm 7$, and $63 \pm 24$, eggs female ${ }^{-1} \mathrm{day}^{-1}$, respectively. In $\mathrm{M} / \mathrm{F}$ and $\mathrm{M}, T_{\mathrm{A}+\mathrm{nystatin}}$ and $T_{\mathrm{D}+\text { nystatin }}$ also presented differences from the control $(p<0.001)$, as the copepods under those antimicrobial treatments did not produce any eggs. $T_{\mathrm{A}+\text { nystatin }}$ showed egg production only in $\mathrm{F}$ (16 \pm 8 ), which was statistically equivalent to the control $(p=0.088)$. No differences in $T_{\mathrm{D}}$ between $\mathrm{M}(13 \pm 8)$ and $\mathrm{F}(8 \pm 5)$ and the control $(p=0.088)$ were observed. In M/F, $36 \pm 21$ eggs were produced, which was significantly higher than the control $(p<0.001)$. $T_{\mathrm{D}+\text { nystatin }}$ only presented egg production in $\mathrm{F}(7 \pm 1)$, with significant differences from the control $(p<0.044) . T_{\mathrm{A}}$ showed higher average egg production $\left(46 \pm 11 \mathrm{eggs}^{\mathrm{female}^{-1}}\right.$ $\left.\mathrm{day}^{-1}\right)$. Among the different antimicrobial application routes, M/F presented the best average results $(25 \pm 11$ eggs female ${ }^{-1}$ day $^{-1}$ ).

Fecal pellet production by $A$. tonsa $\left(\operatorname{copepod}^{-1}\right.$ day $^{-1}$ at $96 \mathrm{~h}$ ) in those routes presented significant differences between treatments $(p<0.001)$ (Fig. 1e). $T_{\mathrm{A}}$ in $\mathrm{M} / \mathrm{F}$ showed a higher average pellet count $(60 \pm 16)$, followed by $\mathrm{M}(60 \pm 26)$ and $\mathrm{F}(22 \pm 17)$; but these values did not statistically differ from the control $(49 \pm 18)$. $T_{\mathrm{A}+\text { nystatin }}$ showed fecal pellet production only in $\mathrm{F}$ ( $28 \pm 10$ ), equivalent to the control. No differences in $T_{\mathrm{D}}$ between the different application methods and the control were observed. When 


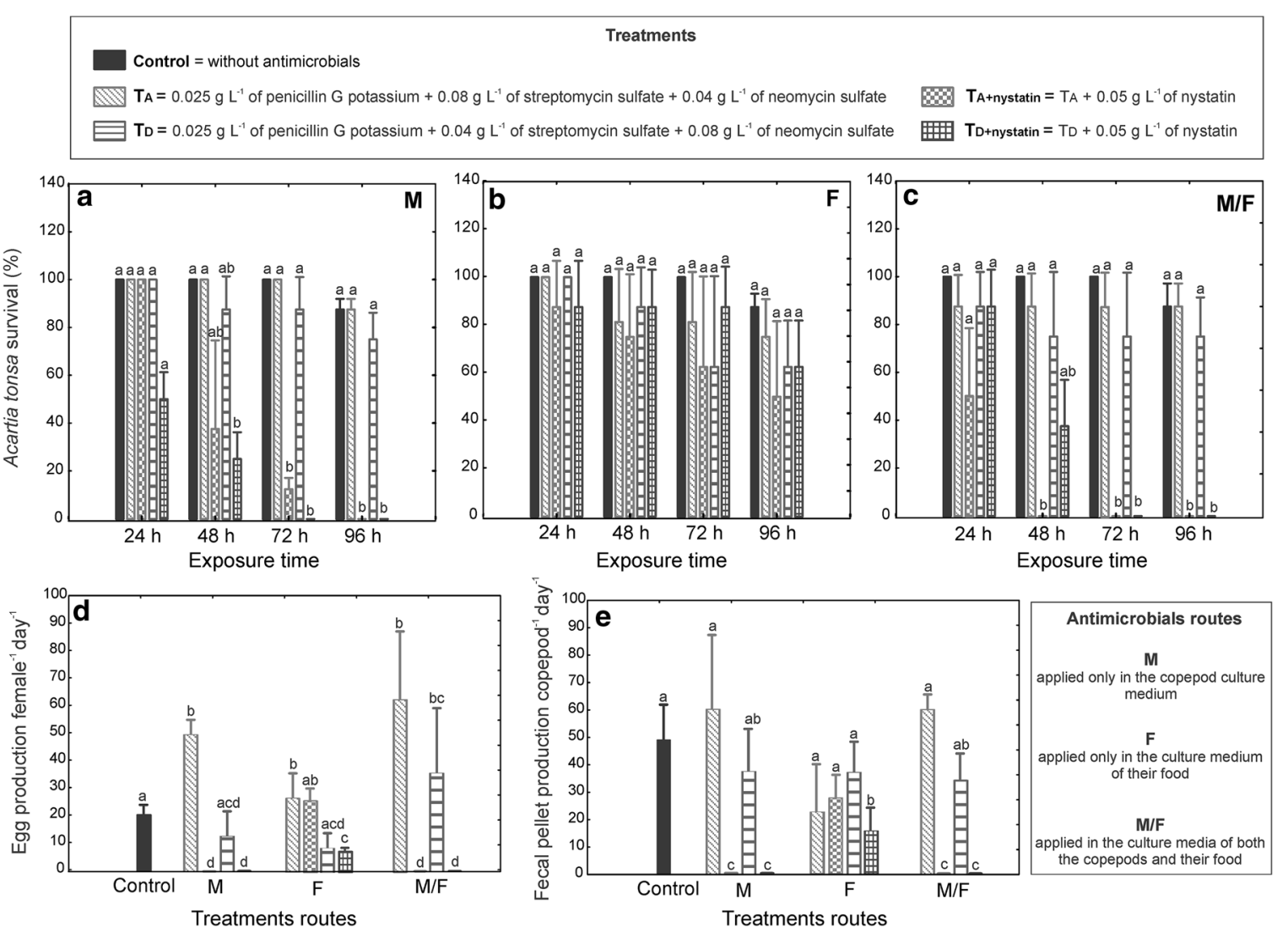

Fig. 1 Acartia tonsa copepod survival and egg and fecal pellet production under different treatments and application routes. a Survival under antimicrobial exposure in the culture medium; (M) b survival under antimicrobial exposure through food (F); c survival under antimicrobial exposure in the culture medium and through food (M/F); d egg production (female ${ }^{-1}$ day $^{-1}$ at $96 \mathrm{~h}$ ); e fecal pellet production (copepod ${ }^{-1} \mathrm{day}^{-1}$ at $96 \mathrm{~h}$ ). The vertical lines denote $95 \%$ confidence intervals (standard error*1.96), and lowercase letters indicate statistical similarities or differences between treatments for each time or situation evaluated

antimicrobials were administered in $\mathrm{M}, 38 \pm 17$ pellets were produced, followed by $\mathrm{F}(37 \pm 12)$ and $\mathrm{M} / \mathrm{F}$ $(35 \pm 10) . T_{\mathrm{D}+\text { nystatin }}$ only presented fecal pellet production in $\mathrm{F}(16 \pm 8)$, with significant differences from the control $(p<0.001)$. Among the antimicrobial application methods, $T_{\mathrm{A}}$ applied in $\mathrm{M} / \mathrm{F}$ and $\mathrm{M}$ showed the best average results.

No differences were observed in A. improvisus survival ( $p>0.991)$ (Fig. 2a) or settlement $(p>0.692)$ (Fig. $2 \mathrm{~b}$ ) between treatments. $T_{\mathrm{A}+\text { nystatin }}$ and $T_{\mathrm{D}}$ showed a lower survival average $(83 \%) . T_{\mathrm{A}+\text { nystatin }}$ also presented a lower settlement percentage at $96 \mathrm{~h}$ of exposure $(50 \%)$. A higher settlement percentage was observed in the control $(83 \%)$, but $T_{\mathrm{A}+\text { nystatin }}$ only settled at $48 \mathrm{~h}$. Significant differences in C. weissflogii growth rates between treatments were also found at $96 \mathrm{~h}(p<0.001)$ (Fig. 2c). At $24 \mathrm{~h}$, no significant differences were observed between all treatments with antimicrobials and the control $\left(109 \pm 76\right.$ cells $\left.\mathrm{mL}^{-1}\right)$, although $T_{\mathrm{A}}$ presented higher growth rates $\left(198 \pm 61\right.$ cells $\left.\mathrm{mL}^{-1}\right)$. At $96 \mathrm{~h}$ of exposure, $T_{\mathrm{A}+\text { nystatin }}(109 \pm 21$ cells $\left.\mathrm{mL}^{-1}\right)$ and $T_{\mathrm{D}+\text { nystatin }}\left(78 \pm 42\right.$ cells $\left.\mathrm{mL}^{-1}\right)$ had a lower average growth rate than the control $\left(266 \pm 100\right.$ cells mL $\left.{ }^{-1}\right)(p<0.001)$. At approximately $168 \mathrm{~h}$ of exposure, only $T_{\mathrm{A}}\left(536 \pm 134\right.$ cells mL $\left.\mathrm{mL}^{-1}\right)$ and $T_{\mathrm{D}}\left(365 \pm 83\right.$ cells $\left.\mathrm{mL}^{-1}\right)$ were different from the control $\left(270 \pm 52\right.$ cells $\left.\mathrm{mL}^{-1}\right)(p<0.001)$, with a higher cell concentration. $T_{\mathrm{A}}$ showed the highest yield $\left(505\right.$ cells $\left.\mathrm{mL}^{-1}\right)$, followed by $T_{\mathrm{D}}\left(333\right.$ cells $\left.\mathrm{mL}^{-1}\right)$, $T_{\mathrm{A}+\text { nystatin }}\left(193\right.$ cells $\left.\mathrm{mL}^{-1}\right)$, the control $\left(177\right.$ cells $\left.\mathrm{mL}^{-1}\right)$, and $T_{\mathrm{D}+\text { nystatin }}\left(162\right.$ cells $\left.\mathrm{mL}^{-1}\right)$.

In the resistance tests with $A$. tonsa, A. improvisus and $C$. weissflogii, the treatments with the antifungal nystatin $\left(0.05 \mathrm{~g} \mathrm{~L}^{-1}\right)$ were the most harmful to non-target organisms, as was the antibiotic concentration $T_{\mathrm{D}}$. Subsequent tests (Table 2) thus applied antimicrobials only in the culture medium, the condition in which the copepod A. tonsa was the most sensitive in the current study. The results presented significant survival rates of 

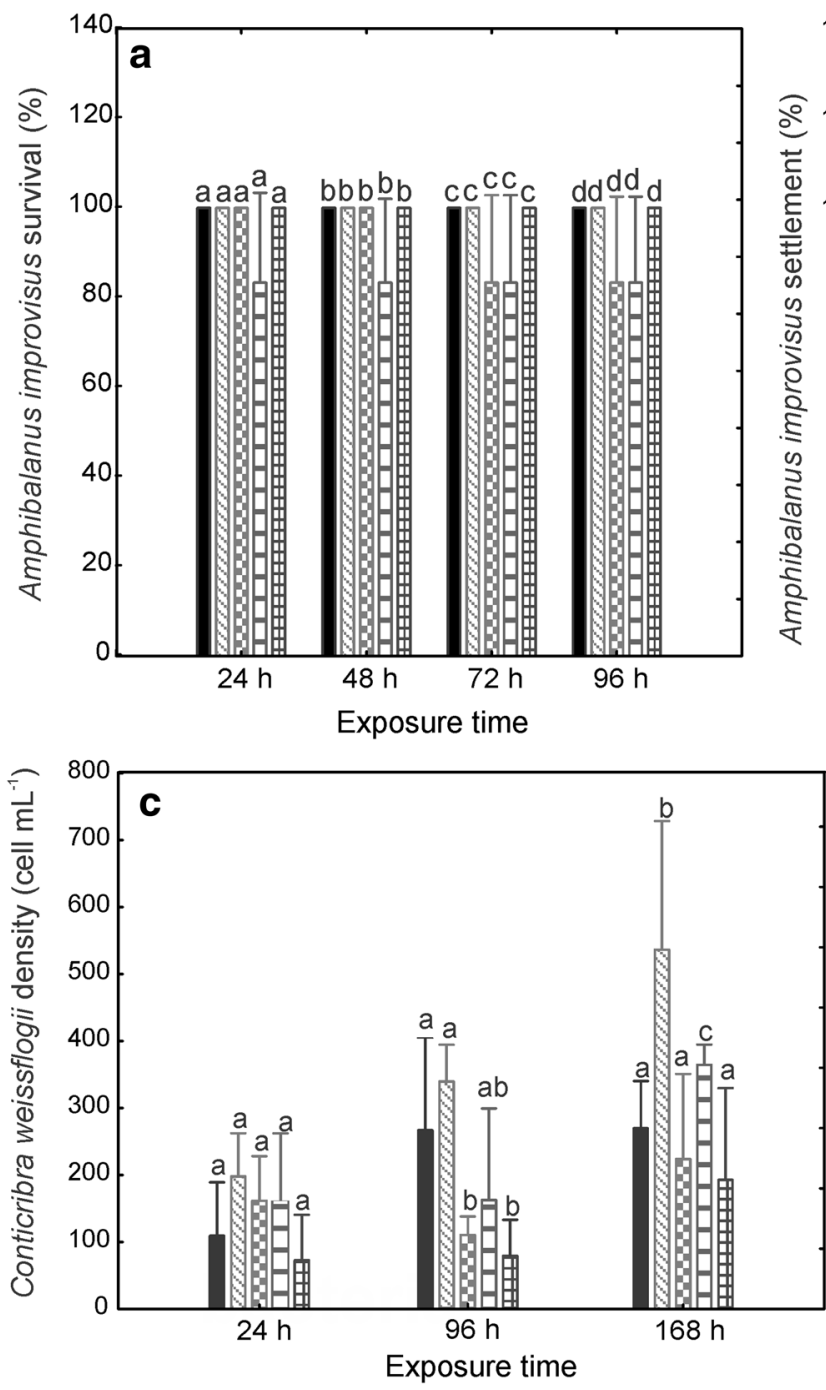
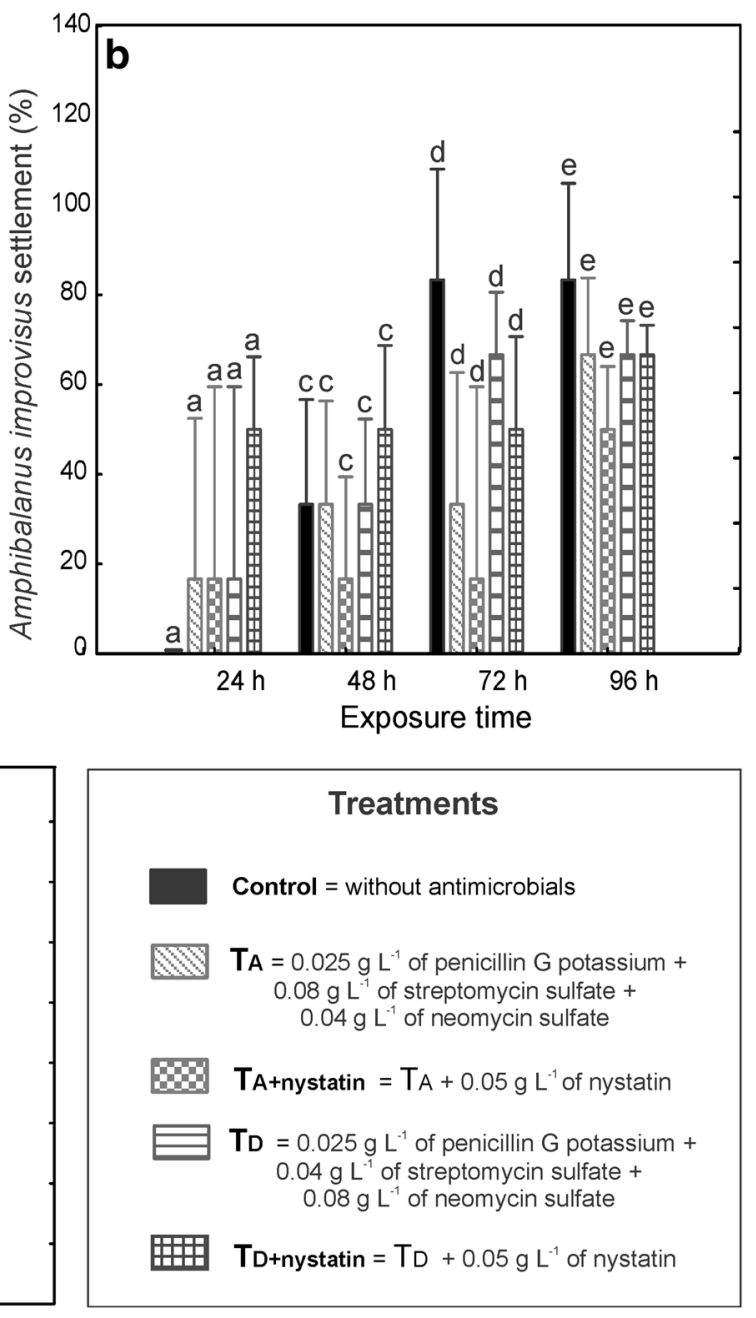

曲冊 $\mathrm{TD}+$ nystatin $=\mathrm{TD}_{\mathrm{D}}+0.05 \mathrm{~g} \mathrm{~L}^{-1}$ of nystatin

Fig. 2 Amphibalanus improvisus cyprid a survival and b settlement at 24, 48, 72 and $96 \mathrm{~h}$; c Conticribra weissflogii diatom growth (cells $\mathrm{mL}^{-1}$ ) at 24,96 , and $168 \mathrm{~h}$ of exposure. The vertical lines denote $95 \%$ confidence intervals (standard error*1.96), and lowercase letters indicate statistical similarities or differences between treatments for each time evaluated

A. tonsa between treatments after $48 \mathrm{~h}$ of exposure. $T_{\mathrm{A}}+\mathrm{n}_{4}$ and $T_{\mathrm{A}}+\mathrm{n}_{5}$ were lethal to copepods, different from the control $(90 \%$ survival) and the other antimicrobial treatments $(p<0.003)$. The same situation occurred at $72 \mathrm{~h}$ of exposure; however, the survivorship in the control was $80 \%(p<0.009)$. At $96 \mathrm{~h}$, no significant differences $(p=0.960)$ between the control (80\% survival) and $T_{\mathrm{A}}\left(100 \%\right.$ survival), $T_{\mathrm{A}}+\mathrm{n}_{1}(70 \%$ survival), and $T_{\mathrm{A}}+\mathrm{n}_{2}\left(65 \%\right.$ survival) were observed. $T_{\mathrm{A}}+\mathrm{n}_{3}\left(20 \%\right.$ survival) $(p<0.009), T_{\mathrm{A}}+\mathrm{n}_{4}(0 \%$ survival) $(p<0.010)$ and $T_{\mathrm{A}}+\mathrm{n}_{5}(0 \%$ survival $)(p<0.034)$, in contrast, showed the lowest survival rates when compared to the control.

The bacterial density (org $\left.\mathrm{cm}^{-2}\right)$ decreased in treatments with antimicrobials $\left(T_{\mathrm{A}}, T_{\mathrm{A}}+\mathrm{n}_{1}\right.$ and $\left.T_{\mathrm{A}}+\mathrm{n}_{2}\right)$, as expected, compared to the control at 3 (p<0.007), $6(p<0.001), 9(p<0.003), 12(p<0.001), 15$ $(p<0.001), 18(p<0.001)$, and $21(p<0.001) \mathrm{h}$ of exposure (Fig. 3a). In the first $3 \mathrm{~h}$ of the experiment, a reduction in the bacterial density $(>26 \%$ ) was observed compared with the control. Between 9 and $15 \mathrm{~h}$, an inhibition of up to $94 \%$ of the biofilm bacterial density was recorded compared to the control. After $15 \mathrm{~h}$, bacterial densities increased in all antimicrobial treatments. The bacteria found in the control and antimicrobial treatments were in the coccus form with similar sizes.

All treatments with antimicrobials had the same cell size (FSC-A), biovolume and biomass values as the control at $12 \mathrm{~h}$ of exposure: $1.11 \mu \mathrm{m}, 0.72 \mu \mathrm{m}^{3}$ and $0.09 \mathrm{pg} \mathrm{C}$ cell $^{-1}$, respectively. All treatments showed just 


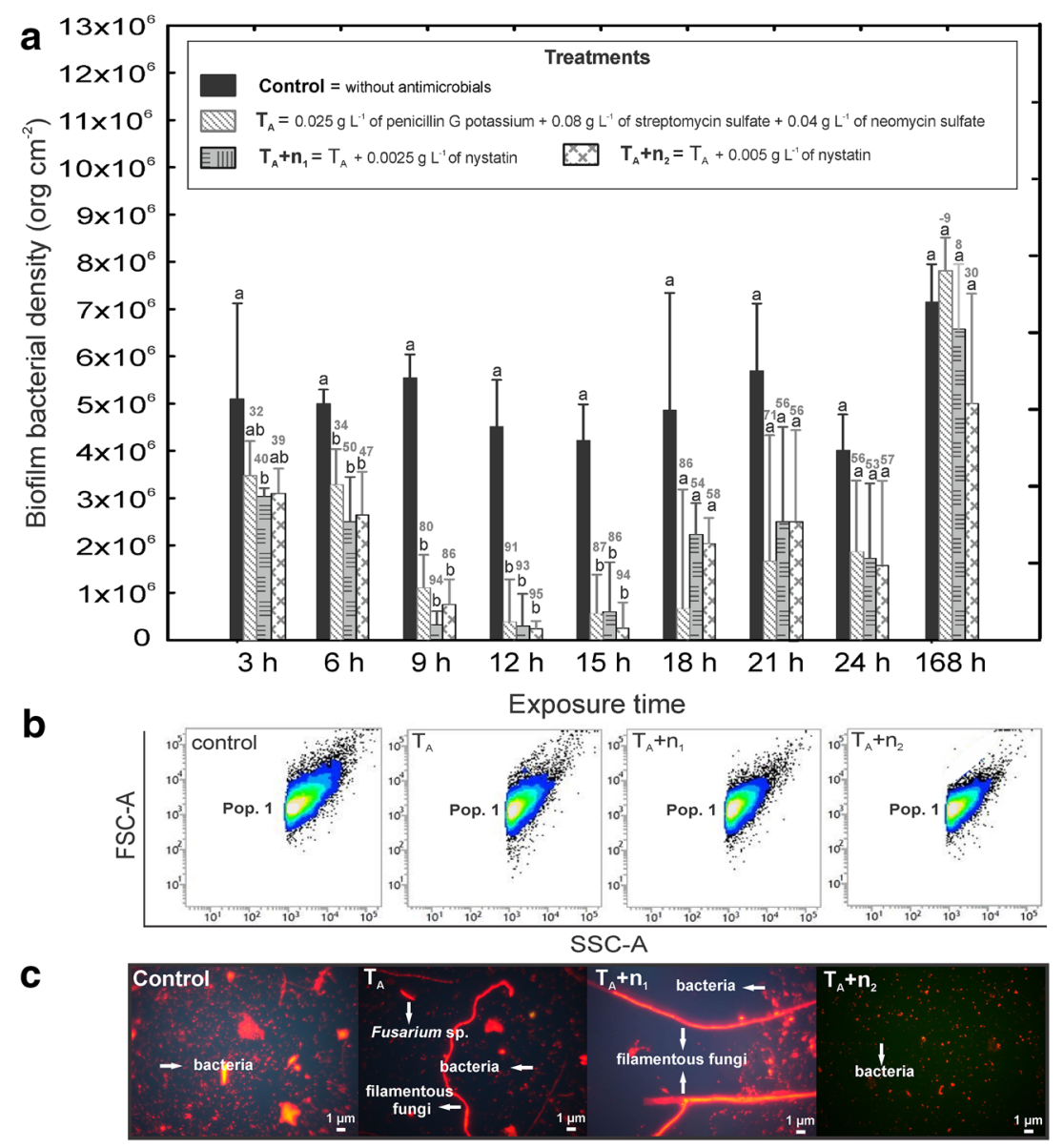

Fig. 3 a Biofilm bacteria density from 3 to $168 \mathrm{~h}$ of exposure. The vertical lines denote $95 \%$ confidence intervals (standard error*1.96). The lowercase letters indicate statistical similarities or differences between treatments at each time evaluated. The numbers above the columns denote the bacteria inhibition percentage (\%) compared to the control. b biofilm bacteria populations by flow cytometer (BD FACSVerse ${ }^{\mathrm{TM}}$ ) after 10,000 acquired events at $12 \mathrm{~h}$. Lighter colors are related to higher density cells; c microbial community under epifluorescence microscope $(\times 1000)$ stained with acridine orange with emphasis on fungi presence/ absence at $168 \mathrm{~h}$

one population and the same cell complexity (SSC-A) (Fig. 3b). The following size, biovolume and biomass were verified independent of treatment using an epifluorescence microscope at $12 \mathrm{~h}: 0.61 \mu \mathrm{m}, 0.12 \mu \mathrm{m}^{3}$, and $0.07 \mathrm{pg} \mathrm{C}$ cell $^{-1}$, respectively. Overall, all antimicrobial treatments were effective in reducing bacterial density, but only $T_{\mathrm{A}}+\mathrm{n}_{2}$ prevented fungal colonization. No fungi were observed in the control. The antimicrobial treatment without nystatin $\left(T_{\mathrm{A}}\right)$ showed filamentous fungi and Fusarium sp., while $T_{\mathrm{A}}+\mathrm{n}_{1}$ showed only a filamentous form (Fig. 3c).

\section{Discussion}

Our findings indicated that the application of $T_{\mathrm{D}}\left(0.025 \mathrm{~g} \mathrm{~L}^{-1}\right.$ penicillin $\mathrm{G}$ potassium $+0.04 \mathrm{~g} \mathrm{~L}^{-1}$ streptomycin sulfate $+0.08 \mathrm{~g} \mathrm{~L}^{-1}$ neomycin sulfate) proposed by DeLorenzo et al. (2001) resulted in a lower survival rate, with lower egg and fecal pellet production for the copepod Acartia tonsa when compared with $T_{\mathrm{A}}\left(0.025 \mathrm{~g} \mathrm{~L}^{-1}\right.$ penicillin $\mathrm{G}$ potassium $+0.08 \mathrm{~g} \mathrm{~L}^{-1}$ streptomycin sulfate $+0.04 \mathrm{~g} \mathrm{~L}^{-1}$ neomycin sulfate $)$ proposed by Agostini et al. (2016). The differences between these two treatments are the streptomycin and neomycin concentrations. The higher concentration of neomycin sulfate $\left(0.08 \mathrm{~g} \mathrm{~L}^{-1}\right)$ proposed by DeLorenzo et al. (2001) caused a greater mortality of A. tonsa than did the same concentration of streptomycin proposed by Agostini et al. (2016). 
Antibiotics such as penicillin, streptomycin and neomycin have been applied in cultures to inhibit bacterial contamination without negative effects in microalgae (Molina-Cárdenas et al. 2016), protozoans (Divan and Schnoes 1982), fish (Forberg et al. 2011), mollusks (Howes et al. 2014), crustaceans (Agostini et al. 2016) and ecological assays with the aquatic community (Middelburg and Nieuwenhuize 2000a, b; DeLorenzo et al. 2001; Veuger et al. 2004; Cozzi and Cantoni 2006; Trottet et al. 2011). The concentration of these antibiotics, however, needs to be evaluated before application in cultures. In this study, $T_{\mathrm{A}}$ and $T_{\mathrm{D}}$, composed only of antibiotics, showed different responses in non-target organisms due to differences in the concentrations of some compounds.

Acartia tonsa, A. improvisus and $C$. weissflogii are possibly more sensitive to high concentrations of neomycin than to streptomycin. Droop (1967), for example, used $0.04 \mathrm{~g} \mathrm{~L}^{-1}$ neomycin in combination with other antibiotics in diatom cultures. Jones et al. (1973) applied only 0.0000001 to $0.000016 \mathrm{~g} \mathrm{~mL}^{-1} \mathrm{mixed}$ with other prokaryotic inhibitors in cyanobacteria cultures, while Green et al. (1967) purified seaweed cultures with $0.0002 \mathrm{~g} \mathrm{~L}^{-1}$ neomycin mixed with other antibiotics. In addition to the lower resistance to $T_{\mathrm{D}}$ compared to $T_{\mathrm{A}}, T_{\mathrm{A}+\mathrm{N}}$ and $T_{\mathrm{D}+\mathrm{N}}$ had lower survival of non-target organisms, probably due to the nystatin concentration used $\left(0.05 \mathrm{~g} \mathrm{~L}^{-1}\right)$.

Kaminski and Montú (2005) reported A. tonsa egg production of 14-34 eggs female ${ }^{-1}$ day $^{-1}$ when fed with Nannochloropsis oculata (Droop) Hibberd and Chaetoceros calcitrans (Paulsen) Takano in excess. Teixeira et al. (1896) observed an average of 28 eggs female ${ }^{-1}$ day $^{-1}$ when fed with $C$. weissflogii at the same concentrations as used this study. The data presented here indicate a beneficial effect of those antibiotics in copepod cultures; our results recorded an average of $63 \mathrm{eggs} \mathrm{female}^{-1}$ day $^{-1}$ in $T_{\mathrm{A}}$ in $\mathrm{M} / \mathrm{F}$ and 49 eggs female $^{-1}$ day $^{-1}$ in $T_{\mathrm{A}}$ in $\mathrm{M}$. In the control, we found 20 eggs female ${ }^{-1}$ day $^{-1}$. The number of fecal pellets produced by copepods can be used as an additional tool to evaluate the nutritional quality of the food (Ianora et al. 1995), although food quality, concentration and size must be considered. Shaw et al. (1994) observed that the culture medium of the copepod Tigriopus californicus (Baker, 1912) without antibiotics had a production rate of 1.6 pellets $\mathrm{h}^{-1}$, while cultures with antibiotics had a production rate of $1.9 \mathrm{pellets}^{-1}$ with the same amount of food. The current study confirms the results of Shaw et al. (1994) because $T_{\mathrm{A}}$ presented higher production of pellets in M/F and M $\left(2.5\right.$ pellets $\left.h^{-1}\right)$ than the control $\left(2.0\right.$ pellets $\left.h^{-1}\right)$. The effect of the antimicrobials on fecal pellets and egg production should be analyzed carefully because production was observed during short periods and the antimicrobials were not replaced, decreasing their effect over the duration of the experiment. The benefit of using antibiotics in cultures was also reported by Tighe-Ford et al. (1970), who used $100 \mu \mathrm{L} \mathrm{L}^{-1}$ Crystamycin $^{\circledR}(0.3 \mathrm{~g}$ of penicillin $\mathrm{G}$ sodium and $0.5 \mathrm{~g}$ of streptomycin sulfate in $2 \mathrm{~mL}$ of distilled water) in barnacle cultures of Austrominius modestus (Darwin 1854) to virtually eliminate bacterial growth and increase the rate of survival of larvae (Tighe-Ford et al. 1970; Harms 1987). The survival of Amphibalanus improvisus in all treatments indicates that these antimicrobials can be applied in cultures of this species without causing lethal damage. Thus, we assume that barnacles are less susceptible than copepods and microalgae. Laboratory cultures allow the study of the growth, development, metamorphosis, fertility and nutritional needs of species as a means of research into the role of organisms in nature (D'Agostino 1975). Thus, the application of $T_{\mathrm{A}}+\mathrm{n}_{2}$ in marine plankton cultures can have different objectives.

We expected that the antimicrobial treatments would lead to lower A. improvisus settlement rates, because the presence of bacterial biofilms has been reported to condition larval settlement of a number of fouling benthic species (Unabia and Hadfield 1999; Lau et al. 2002; Hung et al. 2005; Bao et al. 2010; Agostini et al. 2017), such as barnacles. This relationship was only observed from $72 \mathrm{~h}$ of exposure, when the control reached the highest settlement rate. Because the antibiotics were applied only at the beginning of the cultures, we believe that at $24 \mathrm{~h}$, the effect of the treatments had decreased, resulting again in an increase in the bacterial load.

The use of $T_{\mathrm{A}+\text { nystatin }}, T_{\mathrm{D}}$ and $T_{\mathrm{D}+\text { nystatin }}$ in cultures of the diatom $C$. weissflogii did not produce differences when compared to the control. This indicates the possibility of applying these treatments for purification of microalgae cultures. $T_{\mathrm{A}}$ presented better results than the control, being the most recommended treatment for intensification of microalgal growth. The use of antibiotics in microalgae culture has been reported to be beneficial because bacteria actively compete for the same resources necessary for the survival of phytoplankton (Spencer 1952; Subhash et al. 2004; Hamdan and Jonas 2007). It should be considered, however, that this study was performed only with $C$. weissflogii and that the half-life of antimicrobials reduces the effect over time. In addition, bacteria can mediate a variety of harmful or beneficial interactions with eukaryotic 
organisms. Beneficial interactions would be the acquisition of vitamin $\mathrm{B}_{12}$ through symbiotic relationships with bacteria (Croft et al. 2005). In contrast, the disruption of the microflora would likely delay the development of some juvenile crustaceans (Edlund et al. 2012). Antimicrobial substances can thus affect symbiontmediated interactions in hosts, negatively so if this inhibition continues over time. Lethal effects on microalgae are the lowest when using penicillin compared to other antibiotics (Youn and Hur 2007), although the efficiency of the antibiotics and their concentrations for axenic cultures vary with microalgal species (Lai et al. 2009). The establishment of Bacillariophyceae and Dinophyceae axenic cultures is more difficult than that of Chlorophyceae and Haptophyceae because of their complicated external morphology (Youn and Hur 2007).

Our results indicate that the copepod A. tonsa is more sensitive than A. improvisus and C. weissflogii, especially when treatments are applied only in the culture medium. This result was somewhat expected because this copepod species is very sensitive and is indicated for acute ecotoxicological tests by the International Standardization Organization (ISO 14669 1999). A. tonsa was therefore selected to test the other treatments with different concentrations of nystatin. The results obtained in the settlement of A. improvisus prompted us to re-apply the antimicrobial every $24 \mathrm{~h}$ to maintain the culture medium throughout the experiment. Testing different concentrations of nystatin in combination with $T_{\mathrm{A}}$ revealed that $T_{\mathrm{A}}, T_{\mathrm{A}}+\mathrm{n}_{1}$ and $T_{\mathrm{A}}+\mathrm{n}_{2}$ could be applied to $A$. tonsa cultures. According to Lopes (2014), it is possible to apply up to $0.02 \mathrm{~g}$ $\mathrm{L}^{-1}$ nystatin in combination with antibiotics in cultures without lethal effects on $A$. tonsa for up to $48 \mathrm{~h}$. There was a higher mortality of copepods in the treatments that showed the antifungal nystatin, probably because nystatin is a eukaryotic inhibitory substance (Groll et al. 1999). The use of an antifungal, however, is essential for avoiding fungal contamination due to the ecological niche provided by bacteria (Agostini et al. 2016). Diseases in cultures of invertebrates are caused by fungi of the genera Aspergillus, Penicillium, and Fusarium (Santos et al. 2016).

$T_{\mathrm{A}}, T_{\mathrm{A}}+\mathrm{n}_{1}$ and $T_{\mathrm{A}}+\mathrm{n}_{2}$ showed inhibition in biofilm bacterial density of up to $94 \%$ compared to the control at $9-15 \mathrm{~h}$ of exposure. In this time interval, the microbial community started to restore, and a new dosage of antibiotics was necessary (Agostini et al. 2016). Lopes (2014) obtained adherent bacterial reduction of up to $95 \%$ using the same combination of antimicrobials. Trottet et al. (2011) tested six different antibiotics under laboratory conditions. These authors found that penicillin and streptomycin showed the greatest effectiveness in inhibiting bacterial density. Penicillin targets Gram-positive bacteria; streptomycin targets Gram-negative and Gram-positive bacteria, and neomycin targets Gram-negative bacteria and some Grampositive bacteria. This combination thus inhibits various bacterial species (i.e., Pseudomonas, Vibrio, Agrobacterium, Xanthomonas, Achromobacter, Flavobacterium, Micrococcus, and Staphylococcus) (Berland and Maestrini 1969).

Fungal proliferation could only be avoided by using $T_{\mathrm{A}}+\mathrm{n}_{2}$. To eliminate bacterial and fungal contamination in marine cultures without causing lethal damage to non-target organisms, we suggest the application of $T_{\mathrm{A}}+\mathrm{n}_{2}$. To maintain the culture medium with a minimum bacterial load for more time, antibiotics should be replaced every $12 \mathrm{~h}$. Further studies are therefore necessary to evaluate the effects of these antimicrobials on non-target organisms and to examine alternatives to these substances in culture medium. The antifungal nystatin may be reapplied over a longer time interval, considering that in 7 days ( $168 \mathrm{~h}$ ) of observation, the presence of adherent fungi was not recorded in $T_{\mathrm{A}}+\mathrm{n}_{2}$.

\section{Conclusion}

We found an absence of negative effects on experimental organisms and efficiency in the inhibition of biofilm bacteria using a combination of $0.025 \mathrm{~g} \mathrm{~L}^{-1}$ penicillin $\mathrm{G}$ potassium $+0.08 \mathrm{~g} \mathrm{~L}^{-1}$ streptomycin sulfate $+0.04 \mathrm{~g} \mathrm{~L}^{-1}$ neomycin sulfate diluted in seawater. Nevertheless, the absence of adherent fungi was only observed using $0.005 \mathrm{~g} \mathrm{~L}^{-1}$ nystatin antifungal together with the antibiotics. This concentration of nystatin did not show significant differences from the control regarding A. tonsa survival, but this substance should be avoided if fungal contamination is not a concern because this substance is a eukaryote inhibitor. Species of other planktonic groups should also be tested at this concentration to improve our understanding of the effectiveness of the treatments proposed. 
Acknowledgements The authors acknowledge the support of FAPERGS-PRONEM 16/2551-000244-4, Conselho Nacional de Desenvolvimento Científico e Tecnológico (CNPq-141217/2014-6, 408578/2013-0, 303353/2016-3), and Marine Phytoplankton and Microorganisms Laboratory of the Federal University of Rio Grande and Faculty of Pharmacy of Universidade Federal do Rio Grande do Sul. We thank the veterinarian M Sc. Alice Meirelles Leite for supplying the prescriptions for the antimicrobials, Dr. Lucélia Borges and Biol. Waldemar Appolinário Amaral for their support in the development of the experiments, Mr. Camilo D'Amore for help with cytometer analyses, and M. Sc. Graciéle Cunha Alves for fungi identification.

\section{Compliance with ethical standards}

Ethical approval All procedures performed in studies involving animals were in accordance with the ethical standards of the institution or practice at which the studies were conducted.

Open Access This article is distributed under the terms of the Creative Commons Attribution 4.0 International License (http:// creativecommons.org/licenses/by/4.0/), which permits unrestricted use, distribution, and reproduction in any medium, provided you give appropriate credit to the original author(s) and the source, provide a link to the Creative Commons license, and indicate if changes were made.

\section{References}

Agostini VO (2014) Avaliação dos efeitos do uso de antimicrobianos em cultivos de plâncton marinho. Dissertation, Universidade Federal do Rio Grande, Brasil. 124 pp

Agostini VO, Macedo AJ, Muxagata EM (2016) Evaluation of antibiotics as a methodological procedure to inhibit free-living and biofilm bacteria in marine zooplankton culture. An Acad Bras Cienc 88(1):733-746. https://doi.org/10.1590/00013765201620150454

Agostini VO, MdoN Ritter, Macedo AJ, Muxagata E, Erthal F (2017) What determines sclerobiont colonization on marine mollusk shells? PLoS One 12(9):e0184745. https://doi.org/10.1371/journal.pone.0184745

Bao W-Y, Lee O-O, Chung H-C, Li M, Qian P-Y (2010) Copper affects biofilm inductiveness to larval settlement of the serpulid polychaete Hydroides elegans (Haswell). Biofouling 26:119-128. https://doi.org/10.1080/08927010903329680

Berland BR, Maestrini SY (1969) Action de quelques antibiotiques sur le developpement de cinq diatomlees en culture. J Exp Mar Bio Ecol 3:62-75

Bouvier T, Troussellier M, Anzil A, Courties C, Servais P (2011) Using light scatter signal to estimate bacterial biovolume by flow cytometry. Cytometry 44:188-194

Buttino I, Ianora A, Buono S, Vitiello V, Malzone MG, Rico C, Langellotti A, Sansone G, Gennari L, Miralto A (2012) Experimental cultivation of the Mediterranean calanoid copepod Temora stylifera and Centropages typicus in a pilot recirculation system. Aquaculture 43:247-259. https://doi.org/10.1111/j.1365-2109.2011.02822.x

Caixeta DS, Scarpa TH, Brugnera DF, Freire DO, Alves E, Abreu LR, Piccoli RH (2012) Chemical sanitizers to control biofilms formed by two Pseudomonas species on stainless steel surface. Ciênc Tecnol Aliment 32(1):142-150. https://doi.org/10. 1590/S0101-20612012005000008

Carvalho CCCR, Fernandes P (2010) Production of metabolites as bacterial responses to the marine environment. Mar Drugs 8(3):705-727. https://doi.org/10.3390/md8030705

Cid A, Prado R, Rioboo C, Suarez-Bregua P, Herrero C (2012) Use of microalgae as biological indicators of pollution: looking for new relevant cytotoxicity endpoints. In: Johnsen MN (ed) Microalgae: biotechnology, microbiology and energy. Nova Science Publishers, New York, pp 311-323

Cozzi S, Cantoni C (2006) Partition nitrogen uptake in phytoplankton and bacteria using bactericidal agents and light dependent incubations. Period Biol 108:145-150

Croft MT, Lawrence AD, Raux-Deery E, Warren MJ, Smith AG (2005) Algae acquire vitamin $\mathrm{B}_{12}$ through a symbiotic relationship with bacteria. Nature 438:90-93. https://doi.org/10.1038/nature04056

D'Agostino A (1975) Antibiotics in cultures of invertebrates. In: Smith WL, Chanicy MH (eds) Culture of marine invertebrate animals. Plenum Press, New York, pp 109-133

DeLorenzo ME, Lewitus AJ, Scott GI, Ross PE (2001) Use of metabolic inhibitors to characterize ecological interactions in an estuarine microbial food web. Microb Ecol 42:317-327. https://doi.org/10.1007/s00248-001-0004-1

Divan CL, Schnoes HK (1982) Production of axenic Gonyaulax cultures by treatment with antibiotics. Appl Environ Microbio 44:250-254

Droop MR (1967) A procedure for routine purification of algal cultures with antibiotics. Br Phycol Bull 3:295-297

Edlund A, Ek K, Breitholtz M, Gorokhova E (2012) Antibiotic-induced change of bacterial communities associated with the copepod Nitocra spinipes. PLoS One 7(3):e33107. https://doi.org/10.1371/journal.pone.0033107

Edwards KF, Thomas MK, Klausmeier CA, Litchman E (2016) Phytoplankton growth and the interaction of light and temperature: a synthesis at the species and community level. Limnol Oceanogr 61:1232-1244. https://doi.org/10.1002/lno. 10282

Finley D (2012) Biofiles: cell culture contamination. Sigma-Aldrich 7(1):24

Fitt WK, Hesling GA, Watson TC (1992) Use of antibiotics in the mariculture of giant clams (F. Tridacnidae). Aquaculture 104:1-10. https://doi.org/10.1016/0044-8486(92)90132-5

Forberg T, Arukwe A, Vadstein O (2011) A protocol and cultivation system for gnotobiotic Atlantic cod larvae (Gadus morhua L.) as a tool to study host microbe interactions. Aquaculture 315:222-227. https://doi.org/10.1016/j.aquaculture.2011.02.047 
Freckelton M-L, Nedved BT, Hadfield MG (2017) Induction of invertebrate larval settlement; different bacteria, different mechanisms? Sci Rep 7:42557. https://doi.org/10.1038/srep42557

Gilles S, Fargier L, Lazzaro X, Baras E, De Wilde N, Drakidès C, Amiel C, Rispal B, Blancheton JP (2013) An integrated fishplankton aquaculture system in brackish water. Animal 7(2):322-329. https://doi.org/10.1017/S1751731112001279

Green B, Heilporn V, Limbosch S, Bolonkhere M, Brachet I (1967) The cytoplasmic DNAs of Acetabularia mediterranea. Proc Natl Acad Sci USA 58:1351-1358

Groll AH, Michkiene D, Werner K, Piscitelli S, Walsh TJ (1999) High-performance liquid chromatographic determination of liposomal nystatin in plasma and tissues for pharmacokinetic and tissue distribution studies. J Chromatogr B 735:51-62

Hamdan L, Jonas R (2007) The use of antibiotics to reduce bacterioplankton uptake of phytoplankton extracellular organic carbon (EOC) in the Potomac River estuary. J Exp Mar Biol Ecol 342:242-252. https://doi.org/10.1016/j.jembe.2006.10.054

Harms J (1987) Energy budget for the larval development of Elminius modestus (Crustacea: cirripedia). Helgolinder Meeresun 41:45-67. https://doi.org/10.1007/BF02365099

Herzenberg LA, Tung J, Moore WA, Herzenberg LA, Parks DR (2006) Interpreting flow cytometry data: a guide for the perplexed. Nat Immunol 7(7):681-685. https://doi.org/10.1038/ni0706-681

Howes EL, Bednarsek N, Budenbender J, Comeau S, Doubleday A, Gallager SM, Hopcroft RR, Lischka S, Maas AE, Bijma J, Gattuso J-P (2014) Sink and swim: a status review of thecosome pteropod culture techniques. J Plankton Res 36(2):299-315. https://doi.org/10.1093/plankt/fbu002

Hung OS, Thiyagarajan V, Wu RSS, Qian PY (2005) Effect of ultraviolet radiation on biofilms and subsequent larval settlement of Hydroides elegans. Mar Ecol Prog Ser 304:155-166. https://doi.org/10.3354/meps304155

Ianora A, Poulet SA, Miralto A (1995) A comparative study of the inhibitory effect of diatoms on the reproductive biology of the copepod Temora stylifera. Mar Biol 121:533-539

ISO-International Organization for Standardization (1999) ISO 14669:1999, Water quality—determination of acute lethal toxicity to marine copepods (Copepoda, Crustacea). Geneva

Ithaca NY, Mahmoud AH (1944) Isolation of Trichomonas foetus (Riedmuller, 1928) in bacteria-free cultures by the use of penicillin. Ann Trop Med Parasit 38:219-222

Jones LWG, Crisp DJ (1954) The larval stages of the barnacle Balanus improvisus Darwin. Proc Zool Soc Lond 123:765-780

Jones AK, Rhodes ME, Evans SC (1973) The use of antibiotics to obtain axenic cultures of algae. Brit Phycol J 8:185-196

Kaminski SM, Montú MA (2005) Produção de ovos dos copépodes costeiros Acartia tonsa, Temora stylifera e Temora turbinata, da Praia do Cassino-Rio Grande-RS. Atlântica 27(2):103-111

Lai HT, Hou HH, Su CI, Chen CL (2009) Effects of chloramphenicol, florfenicol, and thiamphenicol on growth of algae Chlorella pyrenoidosa, Isochrysis galbana, and Tetraselmis chui. Ecotox Environ Safe 72:329-334. https://doi.org/10.1016/j.ecoenv. 2008.03.005

Lau SCK, Mak KKW, Chen F, Qian PY (2002) Bioactivity of bacterial strains isolated from marine biofilms in Hong Kong waters for the induction of larval settlement in the marine polychaete Hydroides elegans. Mar Ecol Prog Ser 226:301-310

Lee K-W, Dahms H-U, Park HG, Kang J-H (2013) Population growth and productivity of the cyclopoid copepods Paracyclopina nana, Apocyclops royi and the harpacticoid copepod Tigriopus japonicus in mono and polyculture conditions: a laboratory study. Aquacult Res 44:836-840. https://doi.org/10.1111/j.1365-2109.2011.03071.x

Liu H, Zhou Y, Xiao W, Ji L, Cao X, Song C (2012) Shifting nutrient-mediated interactions between algae and bacteria in a microcosm, evidence from alkaline phosphatase assay. Microbiol Res 167:292-298. https://doi.org/10.1016/j.micres.2011. 10.005

Lopes LFP (2014) Aplicação de antimicrobianos no cultivo de Acartia tonsa (Copepoda:Calanoida): uma ferramenta para a inibição de bactérias e fungos. Universidade Federel do Rio Grande, Rio Grande, Trabalho de Conclusão de Curso, p 38

Lopes LFP, Agostini VO, Muxagata E (2018) Could some procedures commonly used in bioassays with the copepod Acartia tonsa Dana 1849 distort results? Ecotoxicol Environ Saf 150:353-365. https://doi.org/10.1016/j.ecoenv.2017.12.004

López DA, López BA, Pham CK, Isidro EJ, Mde Girolamo (2010) Barnacle culture: background, potential and challenges. Aquacult Res 41:367-375. https://doi.org/10.1111/j.1365-2109.2010.02508.x

McCracken IR (1989) Purifying algal cultures a review of chemical methods. Proc Ns Inst Sci 38:145-168

Middelburg JJ, Nieuwenhuize J (2000a) Uptake of dissolved nitrogen in turbid, tidal estuaries. Mar Ecol Prog Ser 192:79-88

Middelburg JJ, Nieuwenhuize J (2000b) Nitrogen uptake by heterotrophic bacteria and phytoplankton in the nitrate-rich Thames estuary. Mar Ecol Prog Ser 203:13-21

Molina-Cárdenas CA, MdelP Sánchez-Saavedra, Licea-Navarro AF (2016) Decreasing of bacterial content in Isochrysis galbana cultures by using some antibiotics. Rev Biol Mar Oceanogr 51(1):101-112. https://doi.org/10.4067/S071819572016000100010

Norland S (1993) The relationship between biomass and volume of bacteria. In: Kemp PF, Sherr BF, Sherr EB, Cole JJ (eds) Handbook of methods in aquatic microbial ecology. Lewis Publishers, USA, p 777

Oliveira SS, Wasielesky JRW, Ballester ELC, Abreu PC (2006) Caracterização da assembléia de bactérias nitrificantes pelo método "Fluorescent in situ Hybridization" (FISH) no biofilme e água de larvicultura do Camarão-rosa Farfantepenaeus paulensis. Atlântica 28(1):33-45

Piazza V, Ferioli A, Giacco E, Melchiorre N, Valenti A, Delprete F, Biandolino F, Dentone L, Frisenda P, Faimali M (2012) A standardization of Amphibalanus (Balanus) amphitrite (Crustacea, Cirripedia) larval bioassay for ecotoxicological studies. Ecotoxicol Environ Saf 79:134-138. https://doi.org/10.1016/j.ecoenv.2011.12.014

Picot J, Guerin CL, Le Van Kim C, Boulanger CM (2012) Flow cytometry: retrospective, fundamentals and recent instrumentation. Cytotechnology 64:109-130. https://doi.org/10.1007/s10616-011-9415-0

Provasoli L, Pintner I, Packer L (1951) Use of antibiotics in obtaining pure cultures of algae and protozoa. Proc Am Soc Protozool $2: 6$ 
Raisuddin S, Kwok KWH, Leung KMY, Schlenk D, Lee JS (2007) The copepod Tigriopus: a promising marine model organism for ecotoxicology and environmental genomics. Aquat Toxicol 83:161-173. https://doi.org/10.1016/j.aquatox.2007.04.005

Riquelme CE, Avendaño-Herrera R (2003) Microalgae and bacteria interaction in the aquatic environment and their potential use in aquaculture. Rev Chil Hist Nat 76:725-736

Runge JA, Roff JC (2000) The measurement of growth and reproductive rates. In: Harris RP, Wiebe PH, Lenz J, Skjoldal HR, Huntley M (eds) Zooplankton methodology manual. Academy Press, USA, p 684

R Core Team (2016) R: a language and environment for statistical computing. R Foundation for Statistical Computing, Vienna, Austria. https://www.R-project.org/

Sabatini ME (1990) The developmental stages (Copepodids I to VI) of Acartia tonsa Dana, 1849 (Copepoda Calanoida). Crustaceana 59:53-61

Santos A, Hauser-Davis RA, Santos MJ, De Simone SG (2016) Potentially toxic filamentous fungi associated to the economically important Nodipecten nodosus (Linnaeus, 1758) scallop farmed in southeastern Rio de Janeiro, Brazil. Mar Pollut Bull 115:75-79. https://doi.org/10.1016/j.marpolbul.2016.11.058

Scholz B (2014) Purification and culture characteristics of 36 benthic marine diatoms isolated from the Solthörn tidal flat (Southern North Sea). J Phycol 50(4):685-697. https://doi.org/10.1111/jpy.12193

Shaw BA, Harrison RJ, Andersen RJ (1994) Evaluation of the copepod Tigriopus californicus as a bioassay organism for the detection of chemical feeding deterrents produced by marine phytoplankton. Mar Biol 121:89-95

Skjermo J, Vadstein O (1999) Techniques for microbial control in the intensive rearing of marine larvae. Aquaculture 177:333-343. https://doi.org/10.1016/S0044-8486(99)00096-4

Spencer CP (1952) On the use of antibiotics for isolating bacteria-free cultures of marine phytoplankton organisms. J Mar Biol Assoc UK 31:97-106

Støttrup J (2000) The elusive copepods: their production and suitability in marine aquaculture. Aquacult Res 31:703-711. https:// doi.org/10.1046/j.1365-2109.2000.318488.x

Subhash SK, Lipton AP, Paul Raj R (2004) Antibiotic exposure to minimize microbial load in live feed Isochrysis galbana used for larval rearing of Indian pearl oyster Pinctada fucata. Curr Sci 87:25

Sun J, Liu D (2003) Geometric models for calculating cell biovolume and surface area for phytoplankton. J Plankton Res 25(11):1331-1346. https://doi.org/10.1093/plankt/fbg096

Tang KW, Freund CS, Schweitzer CL (2006) Occurrence of copepod carcasses in the lower Chesapeake Bay and their decomposition by ambient microbes. Estuar Coast Shelf Sci 68:499-508. https://doi.org/10.1016/j.ecss.2006.02.021

Teixeira PF, Sonia MK, Avila TR, Cardozo AP, Bersano JGF, Bianchini A (2010) Diet influence on egg production of the copepod Acartia tonsa (Dana 1896). An Acad Bras Cienc 82(2):333-339

Thiyagarajan V, Harder T, Qian PY (2003a) Combined effects of temperature and salinity on larval development and attachment of the subtidal barnacle Balanus trigonus Darwin. J Exp Mar Bio Ecol 287:223-236. https://doi.org/10.1016/S00220981(02)00570-1

Thiyagarajan V, Harder T, Qiu JW, Qian PY (2003b) Energy content at metamorphosis and growth rate of the early juvenile barnacle Balanus amphitrite. Mar Biol 143:543-554

Tighe-Ford DJ, Power MJD, Vaile DC (1970) Laboratory rearing of barnacle larvae for antifouling research. Helgoland Wiss Meer 20:393-405

Trottet A, Fouilland E, Leboulanger C, Lanouguère E, Bouvy M (2011) Use of inhibitors for coastal bacteria and phytoplankton: application to nitrogen uptake measurement. Estuar Coast Shelf S 93:151-159

Unabia CRC, Hadfield MG (1999) Role of bacteria in larval settlement and metamorphosis of the polychaete Hydroides elegans. Mar Biol 133:55-64. https://doi.org/10.1007/s002270050

Veuger B, Middelburg J, Boschker H, Nieuwenhuize J, Rijswijk P, Rochelle-Newall E, Navarro N (2004) Microbial uptake of dissolved organic and inorganic nitrogen in Randers Fjord. Estuar Coast Shelf 61:507-515. https://doi.org/10.1016/j.ecss. 2004.06.014

Wang W (2011) Bacterial diseases of crabs: a review. J Invertebr Pathol 106(1):18-26. https://doi.org/10.1016/j.jip.2010.09.018

Youn J-Y, Hur SB (2007) Antibiotics and their optimum concentration for axenic culture of marine microalgae. Algae 22(3):229-234. https://doi.org/10.4490/algae.2007.22.3.229

Zaritski A (1975) On dimensional determination of rod-shaped bacteria. J Theor Biol 54:243-248

\section{Publisher's Note}

Springer Nature remains neutral with regard to jurisdictional claims in published maps and institutional affiliations. 